\title{
North American Journal of Medical Science
}

\author{
A Peer Reviewed Medical Journal
}

\section{About Us / Issues / For Authors / Submission / Contact Us / Editorial Board}

\section{A Review of the Natural History of Chronic Hepatitis C Infection MARCH 9, 2016 / ADMIN / LEAVE A COMMENT}

[NAJ Med Sci. 2014; 7(1):1-7. DOI: 10.7156/najms.2014.0701001]

Julius Wilder, MD, PhD; Keyur Patel, MD

The burden of chronic hepatitis $C$ infection worldwide is significant. Approximately 4.1 million people in the United States have anti-HCV antibodies. The prevalence worldwide varies, but reaches greater than 3.5\% in some regions (North African, East Asia). The burden of hepatitis $\mathrm{C}$ virus is reflected in the morbidity and mortality of this disease, as well as the societal costs. The morbidity and mortality associated with chronic hepatitis $c$ infection is mostly related to the rate of fibrosis and associated progression to cirrhosis. The natural history of this progression is a complex and dynamic process related to individual characteristics (age, sex, race, genetics), viral characteristics (genotype), behavioral (smoking, alcohol), metabolic factors (insulin resistance, obesity), and co-infection (Hepatitis B and HIV). This review describes the current literature on how these factors interact with chronic hepatitis C infection and impact the natural history of this disease and progression to fibrosis and cirrhosis.

Key Words: chronic hCinfection, anti-HCV antibodies, morbidity, mortality

\section{INTRODUCTION}

Chronic hepatitis $\mathrm{C}(\mathrm{HCV})$ is one of the most common liver diseases in the world and the leading cause of liver transplantation in the United States. The prevalence worldwide ranges from as low as $<1.5 \%$ (Latin America) to as high as $>3.5 \%$ (North Africa, East Asia). ${ }^{1}$ The prevalence of anti-HCV antibodies in the United States is approximately $1.6 \%$ (approximately 4.1 million people). The prevalence of positive HCV RNA is approximately 1.3\% (approximately 3.2 million people). The peak prevalence occurs among persons born between 1945 and 1964 and the strongest risk factor for infection is a history of injection drug use. ${ }^{2}$ The risk of chronic infection after an acute episode of hepatitis $\mathrm{C}$ is high. Studies have shown that after exposure to hepatitis $C$ virus, 80 to 100 percent of patients remain HCV RNA positive, and 60 to 80 percent have persistently elevated liver enzymes. ${ }^{3,4}$

The age-adjusted mortality rate among patients with HCV in the United States in 2007 was 4.6 per 100,000 persons per year. This was higher than the mortality rate for HIV (4.2 deaths per 100,000 persons per year). ${ }^{5}$ Furthermore, approximately $73 \%$ of these deaths occurred in individuals between the ages of 45 and 65 years. ${ }^{5}$ The burden of chronic HCV has been shown to be significant in terms of mortality as well as in terms of societal costs. Chronic HCV accounts for approximately 8000-1300 deaths annually. Furthermore, projections show that between 2010 and 2019 there will be 165,900 deaths from chronic liver disease, 27,200 deaths from hepatocellular carcinoma, and \$10.7 billion in direct

medical expenditures for HCV. Within this model, HCV was shown to lead to the loss of 1.83 million years of life in those younger than 65 and a societal cost of up to $\$ 54.2$ billion. ${ }^{6}$ The goal of this review is to discuss the natural history of HCV infection as well as the predictors of disease outcomes in chronic hepatitis Cinfection.

\section{NATURAL HISTORY OF HEPATITIS C INFECTION}

The majority of patients who acquire HCV do not spontaneously clear the virus and progress on to develop chronic HCV infection. However, defining the natural history of chronic HCV has been difficult because of the long course of the disease

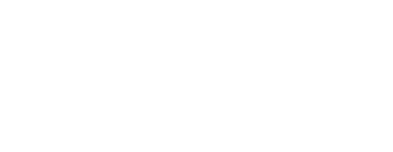

HIGHLIGHT

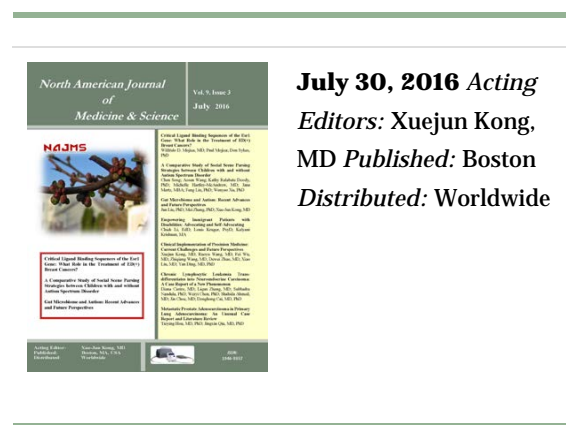

CATEGORIES

Select Category

META

Log in

Entries RSS

Comments RSS

WordPress.org 
and often unknown timing of contracting the disease. Ultimately, chronic HCV results in liver injury that may lead to fibrosis and variable progression to cirrhosis depending on the population. Multiple studies have shown that there are populations who do not progress. ${ }^{8,9}$ Retrospective studies have demonstrated that the risk of developing cirrhosis may be up to 50 percent over 10-20 years in chronically infected patients. However, once advanced fibrosis has developed the annual rate of progression to cirrhosis is approximately 10 percent per year. ${ }^{10-12}$

The majority of morbidity and mortality associated with chronic HCV is seen in patients with cirrhosis. ${ }^{13}$ Of note, not all patients with chronic HCV cirrhosis develop hepatic decompensation. Studies have shown the risk of developing hepatic decompensation to be $3.9 \%$ per year. ${ }^{14}$ The development of cirrhosis is often silent and unrecognized in the majority of patients. ${ }^{10}$ The physical examination may be remarkable for hepatomegaly (68\%) or splenomegaly. ${ }^{10}$ Laboratory findings which suggest progression to fibrosis and cirrhosis include an elevated bilirubin (40\%), hypoalbuminemia (10\%), and decreased platelet counts. ${ }^{15}$ An elevated alpha-feto protein (AFP) is concerning for development of hepatocellular carcinoma (HCC) and any patient with chronic HCV and an elevated AFP should undergo an ultrasound of their liver. However, up to 43 percent of patients with cirrhosis without hepatocellular carcinoma have a serum AFP between 10 and $100 \mathrm{ng} / \mathrm{mL} \cdot{ }^{14-16}$

The majority of deaths from HCV cirrhosis are related to complications from advanced liver disease. However, HCV cirrhosis accounts for approximately one-third of hepatocellular carcinoma cases in the United States and the risk of developing hepatocellular carcinoma once cirrhosis has been shown to be up to $3 \%$ per year. ${ }^{14,17}$ The risk of developing HCC has been shown to be higher among certain HCV genotypes (genotype 1b). ${ }^{18}$

Table 1. Host, Viral, and Behavioural factors that impact disease progression of chronic hepatitis Cinfection.

\begin{tabular}{lll}
\hline Host & Viral & Behavioural \\
\hline Age & $\begin{array}{l}\text { Co-Infection (HIV, } \\
\text { Hepatitis B) }\end{array}$ & Alcohol \\
\hline Sex & HCV Genotype & Smoking \\
\hline $\begin{array}{l}\text { Metabolic (obesity, } \\
\text { insulin resistance) }\end{array}$ & & Coffee \\
\hline
\end{tabular}

\section{Genetics}

Iron Deposition

\section{Factors impacting Disease Progression}

There are multiple host-viral factors which have been shown to impact the progression of disease in chronic HCV. These factors include individual characteristics (age, sex, race, genetics), viral characteristics (genotype), behavioural (smoking, alcohol), metabolic factors (insulin resistance, obesity), and co-infection (Hepatitis B and HIV) (Table 1). Together, these factors impact the degree of fibrosis and progression to cirrhosis as well as the potential for development of hepatocellular carcinoma.

\section{Age}

Age is a known important host factor with respect to disease progression in HCV. However, it is difficult to differentiate age at acquisition from duration of $\mathrm{HCV}$ infection.

A younger age at time of initial infection has been shown to be protective with respect to progression of disease. This relationship remains after controlling for duration of infection. $8,19,20$ Children who have contracted HCV vertically have repeatedly been shown to have very slow progression of liver fibrosis. ${ }^{21,22}$ In one analysis, progression to cirrhosis over 20 years was much lower for those subjects infected before age 20 years (2\%) versus those infected after age 50 years (63\%). ${ }^{8}$ A longer duration of the infection has also been associated with a higher grade of liver fibrosis. ${ }^{23}$ The estimated probability of progression per year for men aged 61- 70 years was 300-times greater than that for men aged 21- 40 years. ${ }^{24-26}$

The precise reason for the variability in progression related to age is unclear. Paired biopsy studies have shown accelerated rates of fibrosis progression over time independent of age of acquisition. ${ }^{24}$ Whether this progression comes with increasing duration of infection or with increasing age is unclear. Another plausible possibility is decreasing rates of fibrosis regression with age..$^{27-28}$ 


\section{Sex}

There appears to be more rapid progression to cirrhosis in males. ${ }^{29}$ Males have been shown to have a rate of progression towards fibrosis 10-times higher than that of females independent of age. ${ }^{25}$ This increased rate of disease progression has been shown after controlling for age, duration of infection, alcohol consumption, and metabolic factors. ${ }^{30}$ Female gender appears to be protective in terms of disease progression, suggesting that hormonal factors may be important in the regulation of liver fibrosis. ${ }^{31}$ In fact, estrogen has been shown in multiple studies to play a role in progression to fibrosis. Estrogen has not only been shown to inhibit proliferation and activity of stellate cells responsible for fibrogenesis, ${ }^{32}$ but also to inhibit IL-6 production by Kupffer cells. The latter has been found to be a potential etiology of increased rates of HCC seen among men versus women. ${ }^{33}$

\section{Race}

Approximately 3.2 million persons in the United States have chronic HCV. ${ }^{34,35}$ African Americans comprise approximately $13 \%$ of the US population, but make up approximately $23 \%$ of Americans with HCV. ${ }^{36}$ A report using NHANES III data (1999-2002) demonstrated that the rate of a positive HCV antibody test was higher in blacks than in whites (3.2\% versus $1.5 \%)$. Within this analysis, Black men had higher rates of infection, with the highest prevalence rate of $9.8 \%$ among black men ages 40 to 49 years. ${ }^{37,38}$ Latinos are the largest growing minority population in the United States and are estimated to represent $25 \%$ of the US population by the year 2050. While the prevalence of HCV in whites within the United States is estimated at 1.5\%, the prevalence among Latino's is estimated at $2.6 \%{ }^{2}$ Although the prevalence of HCV appears to be higher among African Americans, the natural progression of the disease may be less severe when compared to whites. Conversely, there is evidence that the progression of HCV may be more aggressive among Latino's.

Among African Americans, the histological activity and the incidence of liver cirrhosis is lower than in Caucasians. ${ }^{39}$ When compared to their white counterparts, African Americans have been found to have lower rates of fibrosis, ${ }^{40}$ lower alanine aminotransferase (ALT) levels, and reduced inflammatory activity scores on liver biopsy. ${ }^{41}$ While African Americans appear to have a favorable profile with respect to disease progression when compared to whites, Latinos have been found to have an unfavorable profile. Latino patients in the US have a faster progression to cirrhosis when compared to whites. ${ }^{42}$ Asians appear to have a similar disease course as whites. ${ }^{43}$ An important host factor that is impacted by race is the prevalence of IL28B polymorphisms. Single-nucleotide polymorphisms near the interleukin 28B gene (IL28B) have been associated with a two-fold improvement in response to treatment with interferon. This polymorphism has a greater frequency in European than African populations, and explains approximately half of the difference in response rates between African-Americans and patients of European ancestry. ${ }^{44}$

\section{Metabolic Factors}

The prevalence of hepatic steatosis in the United States has been found to be as high as 30-35\% among potential liver donors on biopsy. ${ }^{27,45}$ The occurrence of hepatic steatosis among individuals with HCV is suggested to be as high as 50\%$65 \%{ }^{46}$ Hepatic steatosis has been found to be associated with increased severity of necro-inflammatory activity ${ }^{47,48}$ as well as fibrosis. ${ }^{48}$ The cumulative incidence of HCC has also been found to be higher in the setting of steatosis. ${ }^{49}$ The relationship between steatosis and disease progression in HCV appears to be genotype specific. Hepatic steatosis has been found more frequently and is more severe in the setting of genotype 3 infection versus genotype 1 and 2 infection. ${ }^{50}$

Insulin resistance and diabetes may play a significant role in disease progression in HCV. The presence of insulin resistance has been shown to lead to more severe fibrosis. ${ }^{51,52}$ and decreased response to therapy. ${ }^{53}$ While there is evidence that insulin resistance may impact disease progression in HCV, the relationship is confounded by other known factors which impact disease progression and are closely correlated with diabetes (age, BMI). ${ }^{54}$

\section{Iron}

The underlying pathophysiology of liver damage from HCV is related to oxidative stress. The mechanism for oxidative stress includes activation of pro-oxidant enzymes, weakening of antioxidant defenses, organelle damage, and metals unbalance. ${ }^{55} \mathrm{~A}$ crucial step early in the HCV related oxidative stress process is mitochondrial damage. Mitochondria play a crucial role in energy metabolism and metal homeostasis, primarily iron and copper. Mitochondria are a target for the hepatitis $\mathrm{C}$ virus because many HCV proteins associate with mitochondria during the life cycle of the virus. ${ }^{55}$ The impact that HCV has on mitochondria and metal homeostasis (mainly iron and copper) may partly explain the well-established impact that iron deposition has on the natural history of HCV. Iron overload has been shown to occur in up to $40 \%$ of patients with HCV and has been associated with accelerated fibrosis. ${ }^{27,56,57}$ Iron deposition may also partly explain gender differences between males and women of reproductive age. Furthermore, there is evidence that the immune response of $\mathrm{HCV}$ to interferon is impacted by iron deposition. In the setting of mono-therapy with interferon, a decreased response has 
been shown in those individuals with iron overload on biopsy. ${ }^{58,59}$ Patients with HCV and either hereditary or secondary hemochromatosis have been shown to have accelerated fibrosis ${ }^{60}$ and phlebotomy has been shown to lower ALT (but not response rate) in patients with iron on liver biopsy. ${ }^{61,62}$ Finally, iron overload syndromes are well known non-viral causes of hepatocellular carcinoma, either in combination with viral illnesses (HCV or HBV) or individually (hereditary hemochromatosis). ${ }^{63-64}$

\section{Behavioral Factors}

Both alcohol and smoking impact disease progression in chronic HCV. Alcohol consumption is an independent risk and significant risk factor the development of cirrhosis in the setting of HCV. Intake of more than $50 \mathrm{~g}$ of alcohol daily is associated with increased risk of liver cirrhosis in HCV infected patients. ${ }^{8,65,66}$ Interestingly, there are contradictory studies which have shown a protective effect for in the setting of drinking small amounts of alcohol. Smoking may also be an independent risk factor for development of cirrhosis with chronic HCV. The use of cigarettes has been shown to predict progression to fibrosis in patients with CHC. ${ }^{67,68}$ Similarly, the use of daily cannabis has also been shown to be a predictor of fibrosis progression in $\mathrm{CHC} 1.69$ Conversely, the consumption of coffee has been shown to have a protective effect. Consumption of 3 or more cups of coffee daily has been shown to result in a lower grade of liver fibrosis, decreased steatosis, reduced insulin resistance, and lower ALT levels. ${ }^{70}$ Not only does coffee consumption improve overall mortality in population based studies, ${ }^{71}$ but it also impacts responses to HCV treatment. ${ }^{72}$ Increased coffee intake has been found to increase the likelihood of SVR to antiviral treatment with PEG-IFN and RBV. ${ }^{72}$

\section{Co-infection}

Co-infection with HIV and Hepatitis B virus (HBV) has been shown to impact progression of disease in chronic HCV. HIV appears to impact both immunity and progression of disease in the setting of HCV. ${ }^{27}$ With respect to immunity, HIV+ individuals have quantitative and qualitative abnormalities of their $\mathrm{CD} 4 \mathrm{~T}$ cells. ${ }^{73}$ This results in reduced ability of CD4+ T cells to help viral specific CD8+ T cells. Hence, the hepatitis $\mathrm{C}$ virus in this setting benefits from a reduced viral-specific CD8+ T cell response. Hence, HIV infected individuals con-infected with HCV have greater difficulty controlling their HCV viral loads. ${ }^{74}$ Co-infection with HIV has also been shown to impact disease progression. Patients co-infected with HIV and HCV have more rapid fibrosis progression than mono-infected patients controlling for multiple disease factors known to accelerate fibrosis (age, sex, alcohol consumption). ${ }^{24,75}$ There is also evidence that HIV co-infection results in higher HCV plasma RNA viral loads and increased HCC. ${ }^{27,76,77}$ While HIV co-infection may double the risk of cirrhosis and increase the risk of decompensated liver disease by a factor of 6,78 it appears that HAART therapy may reduce liver related mortality. ${ }^{79}$

Co-infection with HBV and HCV is quite common and likely underestimated due to the potential for occult HBV infection. ${ }^{27,80}$ Co-infection of HBV and HCV typically results in dominance by one virus and suppression of the other. ${ }^{81}$ Regardless, the presence of chronic HBV infection in the setting of chronic HCV has been shown to increase ALT level, result in more rapid development of cirrhosis, and increase the risk of HCC. ${ }^{81,82}$

\section{Genetic Factors}

The excess accumulation of extracellular matrix proteins resulting in fibrogenesis is mediated by necro-inflammation and activation of stellate cells. ${ }^{83}$ Variation in expression of various mRNA's and miRNA's has been shown to impact fibrosis expression. ${ }^{84}$ Multiple small nuclear polypeptides SNPs have been found to increase fibrosis and progression to cirrhosis in chronic HCV. Matrix metalloproteinases (MMPs) play an important role in fibrosis progression and SNPs for both MMP-1 2G homozygote and MMP-9 C allele were more frequent in HCV patients with cirrhosis than in those without cirrhosis. ${ }^{85,86}$ Similarly, recent studies have shown the association of AZIN1 SNP with rapid progression of fibrosis and an allele that delays fibrogenesis through alternative splicing of AZ1N1. ${ }^{87}$ Furthermore, a sequence variation in the patatinlike phospholipase-3 (PNPLA3) has been shown to be strongly associated with high risk of steatosis as well as fibrosis and fibrosis progression in patients with chronic HCV. ${ }^{88}$ A seven SNP variant signature has been identified that is associated with the risk of development of advanced fibrosis in chronic HCV infection as well as estimated fibrosis progression rate. ${ }^{89}$ This cirrhosis risk score (CRS) has been independently validated in small longitudinal cohorts to predict patients with and without progression. ${ }^{90}$ Low 25-OH vitamin D levels and common genetic variations in the vitamin $\mathrm{D}$ receptor gene are also associated with fibrosis progression. ${ }^{91}$

Review of the literature shows that various SNPs are likely associated with fibrosis progression and several extra-cellularmatrix and chemokine mRNAs are probably upregulated in patients with more advanced fibrosis. ${ }^{84}$ However, many of these proposed host genetic factors have not been validated in independent cohorts. Another limitation is that prior studies mostly relied upon cross-sectional and not paired biopsy evaluation, for determination of disease risk and progression. More research is required to better understand the precise host genetic mechanisms involved in progression of chronic 
HCV. Nonetheless, it is clear that underlying genetics within an individual can impact progression of fibrosis and cirrhosis in chronic HCV infection.

\section{Viral Factors}

There is data to support the role of viral factors in the natural history of chronic HCV infection and treatment response. Of note, viral factors do not appear to impact spontaneous HCV clearance. ${ }^{92}$ The studies attempting to further elucidate this relationship have been limited by the difficulty in collecting and characterizing large cohorts of patients soon after seroconversion. ${ }^{93}$ While the role of viral factors in fibrosis progression is still debated for the immunocompetent monoinfected patient, there is evidence to support that HCV genotype may play a role in fibrosis progression. Using a large cohort, Bochud et al 2009 showed that HCV viral genotype-3 was associated with increased rate of fibrosis progression independent of other epidemiological risk factors. ${ }^{94}$ This would correlate with data that has shown increased mortality with genotype $3 .{ }^{95}$ Multiple studies have shown that viral load does not appear to have an impact on disease progression. ${ }^{27}$ Potential mechanisms through which HCV results in increased fibrosis may not be immune related. For example, there are conflicting data in regards to the role of HLA class I and II polymorphisms and fibrosis progression. ${ }^{96-98}$ However, there is data to suggest HCV mediated activation of stellate cells through promotion of steatosis, oxidative stress, and apoptosis may play a role. ${ }^{99,100}$

HCV viral genotype does predict HCV treatment response. The SVR rates among treatment naive individuals with HCV genotype-I using PEG-IFN/RBV are 40-50\%. Conversely the rates using PEG-IFN/RBV are as high as 75\% in genotypes 2 and 3 infection. ${ }^{93,101}$ In the setting of new direct-acting antivirals, SVR rates for genotype-1 are now approaching those of genotype 2 and $3 .{ }^{102}$ However, of note, genotype subset is also an important predictor of treatment response. Among both telaprevir and boceprevir regimens, SVR rates are approximately 10\% lower for HCV genotype-1a compared to genotype1b. ${ }^{103}$ The role of emergent resistance mutations in disease progression amongst patients with incomplete virologic responses to the interferon-sparing oral regimens has not been established.

\section{Mode of Transmission}

The role of mode of transmission in disease progression of chronic HCV remains controversial. Initially there was concern that acquiring HCV through a blood transfusion was associated with higher rates of cirrhosis than seen in the setting of community acquired or childhood acquired HCV. ${ }^{104}$ One large retrospective analysis showed the prevalence of cirrhosis to be $54 \%$ among those who contracted HCV through a blood transfusion, versus $21 \%$ for those who contracted HCV via IV drug abuse. 27,105 These findings raised the possibility that the mode of transmission, perhaps via the size of the inoculum, dictated the risk of progressing to fibrosis. However, subsequent studies have refuted these findings. When correcting for age, other analyses have shown there was no significant difference in development of cirrhosis regardless of mode of transmission. ${ }^{24}$ Mode of acquisition appears to have a limited impact on outcomes, with similar viral clearance and antiHCV antibody seroconversion rates in vertical and transfusion acquired infection. ${ }^{106}$ More research on the potential role of mode of transmission is required. Whether mode of transmission and size of the inoculum are predictive of disease progression is currently unclear.

\section{CONCLUSION}

Chronic HCV infection results in significant morbidity and mortality worldwide. We have provided an overview of the various factors known to have a potential impact on the natural history of chronic HCV infection. While the role of some factors is clear and established (Age, Race, Sex, Co-infection with HIV), others still require further research (genetics, smoking, genotype, mode of transmission). Ultimately, better understanding of host-viral and environmental factors as they relate to the patient will allow for the health care provider to consider potential modifiable disease risk factors and provide an individualized approach to management. Within the past few years there has been rapid evolution of novel innovative antiviral therapies in HCV infection, including new interferon-sparing direct-acting antivirals (DAA's) regimens. These new medications appear safe, well-tolerated and with high efficacy across genotypes, and represent the opportunity for curing hepatitis $\mathrm{C}$ in the majority of diagnosed patients, even in populations where cure rates were previously low with prior standard-of-care therapy. However, most chronic HCV patients remain undiagnosed, and there are still unresolved socioeconomic issues regarding the significant cost and availability of these new regimens. Thus, a better understanding of the natural history of disease progression within the individual will also allow for a tailored approach to treatment related decisions using these emerging medication regimens.

\section{J ulius Wilder, MD, PhD; Keyur Patel, MD*}

${ }^{1}$ Division of Gastroenterology, Duke University School of Medicine, Durham, NC

2 Duke Clinical Research Institute, Durham, NC 
*Corresponding Author: Duke Clinical Research Institute, P.O. Box 17969, DUMC 3850, Durham, NC 27715. Tel: (919) 668-7802. (Email: keyur.patel@duke.edu)

\section{CONFLICT OF INTEREST}

None.

\section{FUNDING AND ACKNOWLEDGEMENTS}

While no funding was directed to obtaining the supply of data, J.W. was supported by the Duke NIDDK Grant No. 5T32DK7568-22; KP -Consultant and/ or Grant/ Research support Gilead Sciences, Vertex, Santaris, BMS, Benitec, Merck.

\section{REFERENCES}

1. Mohd Hanafiah K, Groeger J, Flaxman AD, Wiersma ST. Global epidemiology of hepatitis C virus infection: new estimates of age-specific antibody to HCV seroprevalence. Hepatology. 2013;57(4):1333-1342.

2. Armstrong GL, Wasley A, Simard EP, McQuillan GM, Kuhnert WL, Alter MJ. The prevalence of hepatitis C virus infection in the United States, 1999 through 2002. Ann Intern Med. 2006;144(10):705-714.

3. Farci P, Alter HJ , Wong D, et al. A long-term study of hepatitis C virus replication in non-A, non-B hepatitis. N Engl J Med. 1991;325(2):98-104.

4. Barrera J M, Bruguera M, Ercilla MG, et al. Persistent hepatitis C viremia after acute self-limiting posttransfusion hepatitis C. Hepatology. 1995;21(3):639-644.

5. Ly KN, Xing J, Klevens RM, Jiles RB, Ward JW, Holmberg SD. The increasing burden of mortality from viral hepatitis in the United States between 1999 and 2007. Ann Intern Med. 2012;156(4):271-278.

6. WongJ B, McQuillan GM, McHutchison JG, Poynard T. Estimating future hepatitis C morbidity, mortality, and costs in the United States. Am J Public Health. 2000;90(10):1562-1569.

7. Liang TJ , Rehermann B, Seeff LB, Hoofnagle JH. Pathogenesis, natural history, treatment, and prevention of hepatitis C. Ann Intern Med. 2000;132(4):296-305.

8. Poynard T, Bedossa P, Opolon P. Natural history of liver fibrosis progression in patients with chronic hepatitis C. The OBSVIRC, METAVIR, CLINIVIR, and DOSVIRC groups. Lancet. 1997;349(9055):825-832.

9. Wiese M, Berr F, Lafrenz M, Porst H, Oesen U. Low frequency of cirrhosis in a hepatitis C (genotype $1 \mathrm{~b}$ ) single-source outbreak in germany: a 20-year multicenter study. Hepatology. 2000;32(1):91-96.

10. Tong MJ, el-Farra NS, Reikes AR, Co RL. Clinical outcomes after transfusion-associated hepatitis C. N Engl J Med. 1995;332(22):1463-1466.

11. Yano M, Kumada H, Kage M, et al. The long-term pathological evolution of chronic hepatitis C. Hepatology. 1996;23(6):1334-1340.

12. Dienstag JL, Ghany MG, Morgan TR, et al. A prospective study of the rate of progression in compensated, histologically advanced chronic hepatitis C. Hepatology. 2011;54(2):396-405.

13. Niederau C, Lange S, Heintges T, et al. Prognosis of chronic hepatitis C: results of a large, prospective cohort study. Hepatology. 1998;28(6):1687-1695.

14. Fattovich G, Giustina G, Degos F, et al. Morbidity and mortality in compensated cirrhosis type C: a retrospective follow-up study of 384 patients. Gastroenterology. 1997;112(2):463-472.

15. Adinolfi LE, Giordano MG, Andreana A, et al. Hepatic fibrosis plays a central role in the pathogenesis of thrombocytopenia in patients with chronic viral hepatitis. BrJ Haematol. 2001;113(3):590-595.

16. Merican I, Sherlock S, McIntyre N, Dusheiko GM. Clinical, biochemical and histological features in 102 patients with chronic hepatitis C virus infection. QJ Med. Feb 1993;86(2):119-125.

17. Hu KQ, Tong MJ. The long-term outcomes of patients with compensated hepatitis C virus-related cirrhosis and history of parenteral exposure in the United States. Hepatology. Apr 1999;29(4):1311-1316.

18. Bruno S, Crosignani A, Maisonneuve P, Rossi S, Silini E, Mondelli MU. Hepatitis C virus genotype $1 \mathrm{~b}$ as a major risk factor associated with hepatocellular carcinoma in patients with cirrhosis: a seventeen-year prospective cohort study. Hepatology. Nov 2007;46(5):1350-1356.

19. Minola E, Prati D, Suter F, et al. Age at infection affects the long-term outcome of transfusion-associated chronic hepatitis C. Blood. Jun 15 2002;99(12):4588-4591.

20. Ryder SD, Irving WL, J ones DA, Neal KR, Underwood JC. Progression of hepatic fibrosis in patients with hepatitis C: a prospective repeat liver biopsy study. Gut. 2004;53(3):451-455.

21. Casiraghi MA, De Paschale M, Romano L, et al. Long-term outcome (35 years) of hepatitis C after acquisition of infection through mini transfusions of blood given at birth. Hepatology. J an 2004;39(1):90-96.

22. Tovo PA, Pembrey LJ, Newell ML. Persistence rate and progression of vertically acquired hepatitis C infection. 
European Paediatric Hepatitis C Virus Infection. J Infect Dis. 2000;181(2):419-424.

23. Maasoumy B, Wedemeyer H. Natural history of acute and chronic hepatitis C. Best Pract Res Clin Gastroenterol. 2012;26(4):401-412.

24. Poynard T, Ratziu V, Charlotte F, Goodman Z, McHutchison J, Albrecht J. Rates and risk factors of liver fibrosis progression in patients with chronic hepatitis c. J Hepatol. 2001;34(5):730-739.

25. Deuffic-Burban S, Poynard T, Valleron AJ. Quantification of fibrosis progression in patients with chronic hepatitis C using a Markov model. J Viral Hepat. 2002;9(2):114-122.

26. Massard J, Ratziu V, Thabut D, et al. Natural history and predictors of disease severity in chronic hepatitis C. J Hepatol. 2006;44(1 Suppl):S19-24.

27. Missiha SB, Ostrowski M, Heathcote EJ. Disease progression in chronic hepatitis C: modifiable and nonmodifiable factors. Gastroenterology. 2008;134(6):1699-1714.

28. Seeff LB. Natural history of hepatitis C. Hepatology. 1997;26(3 Suppl 1):21S-28S.

29. Marabita F, Aghemo A, De Nicola S, et al. Genetic variation in the interleukin-28B gene is not associated with fibrosis progression in patients with chronic hepatitis C and known date of infection. Hepatology. 2011;54(4):1127-1134.

30. Ratziu V, Munteanu M, Charlotte F, Bonyhay L, Poynard T. Fibrogenic impact of high serum glucose in chronic hepatitis C. J Hepatol. 2003;39(6):1049-1055.

31. Yasuda M, Shimizu I, Shiba M, Ito S. Suppressive effects of estradiol on dimethylnitrosamine-induced fibrosis of the liver in rats. Hepatology. 1999;29(3):719-727.

32. Bissell DM. Sex and hepatic fibrosis. Hepatology. 1999;29(3):988-989.

33. Naugler WE, Sakurai T, Kim S, et al. Gender disparity in liver cancer due to sex differences in MyD88-dependent IL-6 production. Science. 2007;317(5834):121-124.

34. Lavanchy D. The global burden of hepatitis C. Liver international : official journal of the International Association for the Study of the Liver. 2009;29 (Suppl 1):74-81.

35. Centers for Disease Control and Prevention. Hepatitis C Information for Health Professionals. Centers for Disease Control and Prevention 2008; http:// www.cdc.gov/ hepatitis/hcv/ .

36. Armstrong GL, Wasley A, Simard EP, McQuillan GM, Kuhnert WL, Alter MJ. The prevalence of hepatitis C virus infection in the United States, 1999 through 2002. Ann Intern Med. 2006;144(10):705-714.

37. NIH consensus statement on management of hepatitis C: 2002. NIH consensus and state-of-the-science statements. 2002; Vol 192002:1-46.

38. Alter MJ, Kruszon-Moran D, Nainan OV, et al. The prevalence of hepatitis C virus infection in the United States, 1988 through 1994. N Engl J Med. 1999;341(8):556-562.

39. Crosse K, Umeadi OG, Anania FA, et al. Racial differences in liver inflammation and fibrosis related to chronic hepatitis C. Clin Gastroenterol Hepatol. 2004;2(6):463-468.

40. Wiley TE, Brown J, Chan J . Hepatitis C infection in African Americans: its natural history and histological progression. Am J Gastroenterol. 2002;97(3):700-706.

41. Sterling RK, Stravitz RT, Luketic VA, et al. A comparison of the spectrum of chronic hepatitis C virus between Caucasians and African Americans. Clin Gastroenterol Hepatol. 2004;2(6):469-473.

42. Bonacini M, Groshen MD, Yu MC, Govindarajan S, Lindsay KL. Chronic hepatitis C in ethnic minority patients evaluated in Los Angeles County. AmJ Gastroenterol. 2001;96(8):2438-2441.

43. D’Souza R, Glynn MJ, Ushiro-Lumb I, et al. Prevalence of hepatitis C-related cirrhosis in elderly Asian patients infected in childhood. Clin Gastroenterol Hepatol. 2005;3(9):910-917.

44. Ge D, Fellay J Thompson AJ, et al. Genetic variation in IL28B predicts hepatitis C treatment-induced viral clearance. Nature. 2009;461(7262):399-401.

45. Ryan CK, J ohnson LA, Germin BI, Marcos A. One hundred consecutive hepatic biopsies in the workup of living donors for right lobe liver transplantation. Liver Transpl. 2002;8(12):1114-1122.

46. Hwang SJ, Luo JC, Chu CW, et al. Hepatic steatosis in chronic hepatitis C virus infection: prevalence and clinical correlation. J Gastroenterol Hepatol. 2001;16(2):190-195.

47. Fiore G, Fera G, Napoli N, Vella F, Schiraldi O. Liver steatosis and chronic hepatitis C: a spurious association? Eur J Gastroenterol Hepatol. 1996;8(2):125-129.

48. Adinolfi LE, Gambardella M, Andreana A, Tripodi MF, Utili R, Ruggiero G. Steatosis accelerates the progression of liver damage of chronic hepatitis C patients and correlates with specific HCV genotype and visceral obesity. Hepatology. 2001;33(6):1358-1364.

49. Ohata K, Hamasaki K, Toriyama K, et al. Hepatic steatosis is a risk factor for hepatocellular carcinoma in patients with chronic hepatitis C virus infection. Cancer. 2003;97(12):3036-3043. 
50. Westin J, Nordlinder H, Lagging M, Norkrans G, Wejstal R. Steatosis accelerates fibrosis development over time in hepatitis C virus genotype 3 infected patients. J Hepatol. 2002;37(6):837-842.

51. Hui JM, Sud A, Farrell GC, et al. Insulin resistance is associated with chronic hepatitis C virus infection and fibrosis progression [corrected]. Gastroenterology. 2003;125(6):1695-1704.

52. McCaughan GW, George J . Fibrosis progression in chronic hepatitis C virus infection. Gut. 2004;53(3):318-321.

53. Romero-Gomez M, Del Mar Viloria M, Andrade RJ, et al. Insulin resistance impairs sustained response rate to peginterferon plus ribavirin in chronic hepatitis C patients. Gastroenterology. 2005;128(3):636-641.

54. Friedenberg F. Hepatitis $C$ and diabetes: an update from the National Health and Nutrition Examination Survey (abstr). Gastroenterology. 2007;132(A775).

55. Arciello M, Gori M, Balsano C. Mitochondrial Dysfunctions and Altered Metals Homeostasis: New Weapons to Counteract HCV-Related Oxidative Stress. Oxid Med Cell Longev. 2013;2013:971024.

56. Haque S, Chandra B, Gerber MA, Lok AS. Iron overload in patients with chronic hepatitis C: a clinicopathologic study. Hum Pathol. 1996;27(12):1277-1281.

57. Bonkovsky HL, Banner BF, Rothman AL. Iron and chronic viral hepatitis. Hepatology. 1997;25(3): 759-768.

58. Olynyk J K, Reddy KR, Di Bisceglie AM, et al. Hepatic iron concentration as a predictor of response to interferon alfa therapy in chronic hepatitis C. Gastroenterology. 1995;108(4):1104-1109.

59. Fargion S, Fracanzani AL, Rossini A, et al. Iron reduction and sustained response to interferon-alpha therapy in patients with chronic hepatitis C: results of an Italian multicenter randomized study. Am J Gastroenterol. 2002;97(5):1204-1210.

60. Diwakaran HH, Befeler AS, Britton RS, Brunt EM, Bacon BR. Accelerated hepatic fibrosis in patients with combined hereditary hemochromatosis and chronic hepatitis Cinfection. J Hepatol. 2002;36(5):687-691.

61. Yano M, Hayashi H, Wakusawa S, et al. Long term effects of phlebotomy on biochemical and histological parameters of chronic hepatitis C. AmJ Gastroenterol. 2002;97(1):133-137.

62. Di Bisceglie AM, Bonkovsky HL, Chopra S, et al. Iron reduction as an adjuvant to interferon therapy in patients with chronic hepatitis $\mathrm{C}$ who have previously not responded to interferon: a multicenter, prospective, randomized, controlled trial. Hepatology. 2000;32(1):135-138.

63. Tirnitz-Parker JE, Glanfield A, Olynyk JK, Ramm GA. Iron and hepatic carcinogenesis. Crit Rev Oncog. 2013;18(5):391-407.

64. Hamed MA, Ali SA. Non-viral factors contributing to hepatocellular carcinoma. World J Hepatol. 2013;5(6):311-322.

65. Zarski JP, Mc Hutchison J , Bronowicki JP, et al. Rate of natural disease progression in patients with chronic hepatitis C. J Hepatol. Mar 2003;38(3):307-314.

66. Monto A, Patel K, Bostrom A, et al. Risks of a range of alcohol intake on hepatitis C-related fibrosis. Hepatology. 2004;39(3):826-834.

67. Hezode C, Lonjon I, Roudot-Thoraval F, et al. Impact of smoking on histological liver lesions in chronic hepatitis C. Gut. 2003;52(1):126-129.

68. Dev A, Patel K, Conrad A, Blatt LM, McHutchison JG. Relationship of smoking and fibrosis in patients with chronic hepatitis C. Clin Gastroenterol Hepatol. 2006;4(6):797-801.

69. Hezode C, Roudot-Thoraval F, Nguyen S, et al. Daily cannabis smoking as a risk factor for progression of fibrosis in chronic hepatitis C. Hepatology. 2005;42(1):63-71.

70. Freedman ND, Everhart JE, Lindsay KL, et al. Coffee intake is associated with lower rates of liver disease progression in chronic hepatitis C. Hepatology. 2009;50(5):1360-1369.

71. Altekruse SF, McGlynn KA, Reichman ME. Hepatocellular carcinoma incidence, mortality, and survival trends in the United States from 1975 to 2005. J Clin Oncol. 2009;27(9):1485-1491.

72. Freedman ND, Curto TM, Lindsay KL, Wright EC, Sinha R, Everhart JE. Coffee consumption is associated with response to peginterferon and ribavirin therapy in patients with chronic hepatitis C. Gastroenterology. 2011;140(7):1961-1969.

73. Lane HC, Depper JM, Greene WC, Whalen G, Waldmann TA, Fauci AS. Qualitative analysis of immune function in patients with the acquired immunodeficiency syndrome. Evidence for a selective defect in soluble antigen recognition. N Engl J Med. 1985;313(2):79-84.

74. Kim AY, Schulze zur Wiesch J, Kuntzen T, et al. Impaired hepatitis $C$ virus-specific $\mathrm{T}$ cell responses and recurrent hepatitis C virus in HIV coinfection. PLoS Med. 2006;3(12):e492.

75. Soriano V, Sulkowski M, Bergin C, et al. Care of patients with chronic hepatitis C and HIV co-infection: recommendations from the HIV-HCV International Panel. AIDS. 2002;16(6):813-828.

76. Eyster ME, Fried MW, Di Bisceglie AM, Goedert JJ. Increasing hepatitis C virus RNA levels in hemophiliacs: relationship to human immunodeficiency virus infection and liver disease. Multicenter Hemophilia Cohort Study. 
Blood. 1994;84(4):1020-1023.

77. Pol S, Lamorthe B, Thi NT, et al. Retrospective analysis of the impact of HIV infection and alcohol use on chronic hepatitis C in a large cohort of drug users. J Hepatol. 1998;28(6):945-950.

78. Merriman NA, Porter SB, Brensinger CM, Reddy KR, Chang KM. Racial difference in mortality among U.S. veterans with HCV/HIV coinfection. Am J Gastroenterol. 2006;101(4):760-767.

79. Qurishi N, Kreuzberg C, Luchters G, et al. Effect of antiretroviral therapy on liver-related mortality in patients with HIV and hepatitis C virus coinfection. Lancet. 2003;362(9397):1708-1713.

80. Cacciola I, Pollicino T, Squadrito G, Cerenzia G, Orlando ME, Raimondo G. Occult hepatitis B virus infection in patients with chronic hepatitis Cliver disease. N Engl J Med. 1999;341(1):22-26.

81. Zarski J P, Bohn B, Bastie A, et al. Characteristics of patients with dual infection by hepatitis B and Cviruses. J Hepatol. 1998;28(1):27-33.

82. Gaeta GB, Stornaiuolo G, Precone DF, et al. Epidemiological and clinical burden of chronic hepatitis B virus/ hepatitis Cvirus infection. A multicenter Italian study. J Hepatol. 2003;39(6):1036-1041.

83. Marcellin P, Asselah T, Boyer N. Fibrosis and disease progression in hepatitis C. Hepatology. 2002;36(5 Suppl 1):S4756.

84. Estrabaud E, Vidaud M, Marcellin P, Asselah T. Genomics and HCV infection: progression of fibrosis and treatment response. J Hepatol. 2012;57(5):1110-1125.

85. Okamoto K, Mimura K, Murawaki Y, Yuasa I. Association of functional gene polymorphisms of matrix metalloproteinase (MMP)-1, MMP-3 and MMP-9 with the progression of chronic liver disease. J Gastroenterol Hepatol. 2005;20(7):1102-1108.

86. Reynolds WF, Patel K, Pianko S, Blatt LM, Nicholas JJ, McHutchison JG. A genotypic association implicates myeloperoxidase in the progression of hepatic fibrosis in chronic hepatitis $\mathrm{C}$ virus infection. Genes Immun. 2002;3(6):345-349.

87. Paris AJ, Snapir Z, Christopherson CD, et al. A polymorphism that delays fibrosis in hepatitis C promotes alternative splicing of AZIN1, reducing fibrogenesis. Hepatology. 2011;54(6):2198-2207.

88. Trepo E, Pradat P, Potthoff A, et al. Impact of patatin-like phospholipase-3 (rs738409 C>G) polymorphism on fibrosis progression and steatosis in chronic hepatitis C. Hepatology. 2011;54(1):60-69.

89. Huang H, Shiffman ML, Friedman S, et al. A 7 gene signature identifies the risk of developing cirrhosis in patients with chronic hepatitis C. Hepatology. 2007;46(2):297-306.

90. Marcolongo M, Young B, Dal Pero F, et al. A seven-gene signature (cirrhosis risk score) predicts liver fibrosis progression in patients with initially mild chronic hepatitis C. Hepatology. 2009;50(4):1038-1044.

91. Baur K, Mertens JC, Schmitt J, et al. Combined effect of 25-OH vitamin D plasma levels and genetic vitamin D receptor (NR 1I1) variants on fibrosis progression rate in HCV patients. Liver Int. 2012;32(4):635-643.

92. Micallef JM, Kaldor JM, Dore GJ. Spontaneous viral clearance following acute hepatitis C infection: a systematic review of longitudinal studies. J Viral Hepat. 2006;13(1):34-41.

93. Doyle JS, Hellard ME, Thompson AJ. The role of viral and host genetics in natural history and treatment of chronic HCV infection. Best Pract Res Clin Gastroenterol. 2012;26(4):413-427.

94. Bochud PY, Cai T, Overbeck K, et al. Genotype 3 is associated with accelerated fibrosis progression in chronic hepatitis C. J Hepatol. 2009;51(4):655-666.

95. Backus LI, Boothroyd DB, Phillips BR, Belperio P, Halloran J, Mole LA. A sustained virologic response reduces risk of all-cause mortality in patients with hepatitis C. Clin Gastroenterol Hepatol. 2011;9(6):509-516.

96. Hue S, Cacoub P, Renou C, et al. Human leukocyte antigen class II alleles may contribute to the severity of hepatitis C virus-related liver disease. J Infect Dis. 2002;186(1):106-109.

97. Tillmann HL, Chen DF, Trautwein C, et al. Low frequency of HLA-DRB1*11 in hepatitis C virus induced end stage liver disease. Gut. 2001;48(5):714-718.

98. Patel K, Norris S, Lebeck L, et al. HLA class I allelic diversity and progression of fibrosis in patients with chronic hepatitis C. Hepatology. 2006;43(2):241-249.

99. Okuda M, Li K, Beard MR, et al. Mitochondrial injury, oxidative stress, and antioxidant gene expression are induced by hepatitis C virus core protein. Gastroenterology. 2002;122(2):366-375.

J0. Chou AH, Tsai HF, Wu YY, et al. Hepatitis C virus core protein modulates TRAIL-mediated apoptosis by enhancing Bid cleavage and activation of mitochondria apoptosis signaling pathway. J Immunol. 2005;174(4):2160-2166.

01. Pearlman BL, Traub N. Sustained virologic response to antiviral therapy for chronic hepatitis C virus infection: a cure and so much more. Clin Infect Dis. 2011;52(7):889-900.

02. Jacobson IM, McHutchison JG, Dusheiko G, et al. Telaprevir for previously untreated chronic hepatitis C virus infection. N Engl J Med. 2011;364(25):2405-2416. 
03. Lok AS, Gardiner DF, Lawitz E, et al. Preliminary study of two antiviral agents for hepatitis C genotype 1. N Engl J Med. 2012;366(3):216-224.

04. Di Bisceglie AM, Goodman ZD, Ishak KG, Hoofnagle JH, Melpolder JJ, Alter HJ. Long-term clinical and histopathological follow-up of chronic posttransfusion hepatitis. Hepatology. 1991;14(6):969-974.

05. Gordon SC, Bayati N, Silverman AL. Clinical outcome of hepatitis C as a function of mode of transmission. Hepatology. 1998;28(2):562-567.

06. Rerksuppaphol S, Hardikar W, Dore GJ. Long-term outcome of vertically acquired and post-transfusion hepatitis C infection in children. J Gastroenterol Hepatol. 2004;19(12):1357-1362.

ADMIN

PREVIOUS ARTICLE YIQING SONG, MD, SCD
NEXT ARTICLE

SARCOMATOID HIGH GRADE UROTHELIAL

CARCINOMA WITH

RHABDOMYOSARCOMATOUS AND OTHER

DIFFERENTIATION: A CASE REPORT WITH

REVIEW OF LITERATURE [ABSTRACT]

\section{LEAVE A REPLY}

Your email address will not be published. Required fields are marked *

COMMENT

$\mathrm{NAME} *$

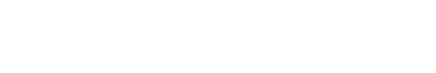

EMAIL*

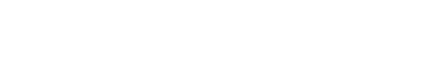

WEBSITE

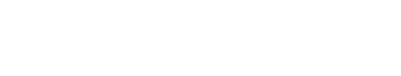

Post Comment 